\title{
Systematic analytical differences between psoas major and longissimus dorsi muscles of cattle
}

\author{
BY R. A. LAWRIE \\ Low Temperature Research Station, Cambridge \\ (Received 6 February r96r-Revised 10 April 1961)
}

It is clear from the investigations of Hammond (1932) and McMeekan (I940a-c, I94I) that further understanding of the development of meat animals requires detailed knowledge of the chemical and biochemical characteristics of individual muscles and of the factors causing variation in their composition. The psoas major and longissimus dorsi muscles of beef animals, frequently referred to in the meat trade as under fillet and top fillet respectively, represent portions of the carcass particularly valuable commercially and gastronomically. Differences between these two muscles in the pattern of post-mortem glycolysis (Howard \& Lawrie, I956; Kronman, Weinberger \& Winterbottom, 1960) and in their relative susceptibility to freezing damage (Howard, Lawrie \& Lee, I960) have previously been shown. In the present paper a comparison. of the distribution of protein nitrogen and of the content of intramuscular fat is made.

\section{METHODS}

Animals. Samples were obtained from five young Ayrshire $\times$ Red Poll bulls aged 4-16 months, from a Friesian steer and an Aberdeen-Angus heifer, both aged I 8 months, and from a West Highland steer aged 32 months.

Sampling. Although the ages and breeds of the animals varied, the parts of the two muscles studied were paired samples from the same area of each carcass. Those portions of the longissimus dorsi and psoas major muscles corresponding to the $4^{\text {th }}$, $5^{\text {th }}$ and 6 th lumbar vertebrae were dissected from the left-hand sides of the carcasses at a standard time of $24 \mathrm{~h}$ post mortem. The muscular tissue, after being freed from the intermuscular fat and aggregates of connective tissue, was minced twice and thoroughly mixed before analysis.

Analysis. The methods of analysis were the same as those described earlier (Lawrie, I960).

\section{RESULTS}

The contents of intramuscular fat (and its iodine value), dry matter and total, nonprotein, sarcoplasmic, myofibrillar and stroma nitrogen, in the psoas major and longissimus dorsi muscles are given in Table $\mathrm{I}$. The results have been arranged in order of the age of the animals. 


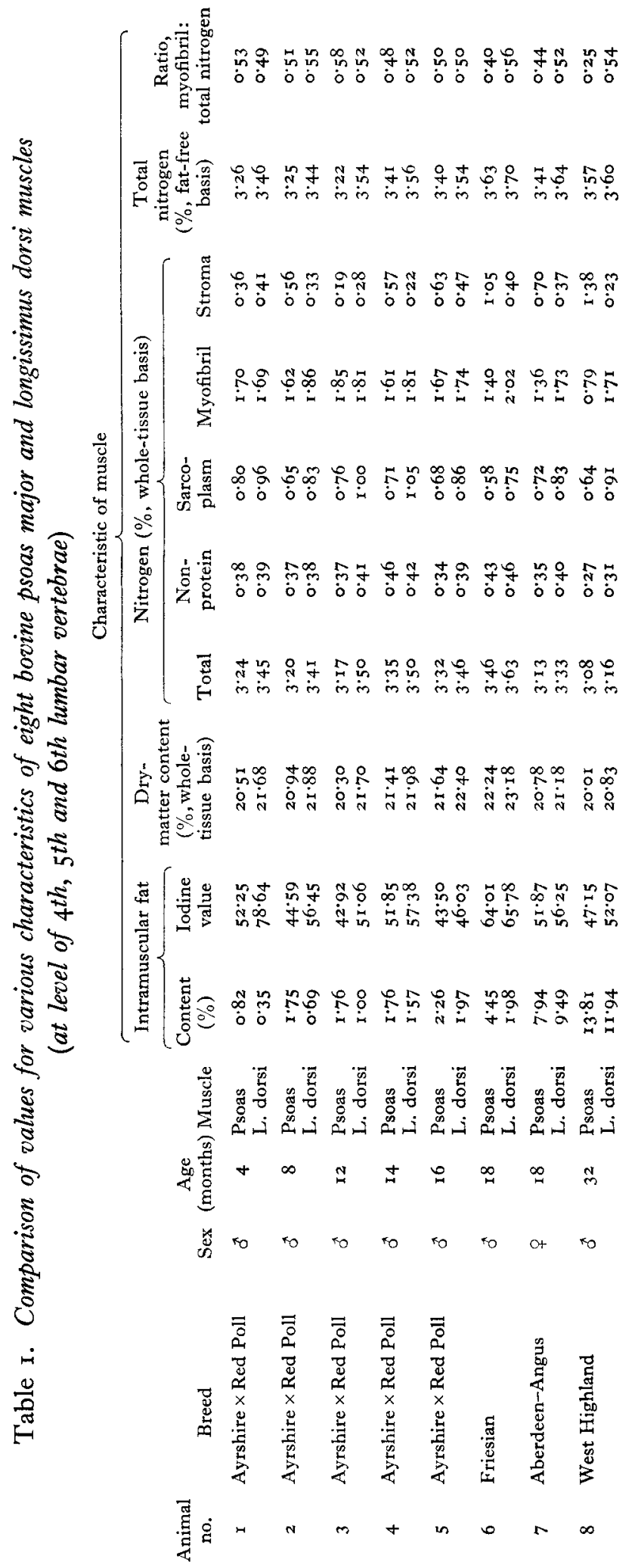




\section{DISCUSSION}

The results permit two apparently contradictory interpretations. On the one hand, it is evident that there was a greater concentration of intramuscular fat in the psoas than in the corresponding longissimus dorsi muscle and that the iodine value of the fat in the former was considerably less. This was the finding in all but one of the various animals studied, irrespective of the general tendency for intramuscular fat to increase with age in both muscles. It has been suggested that a relatively greater concentration of intramuscular fat, when nutritional and other relevant influences are not implicated, reflects a more active type of muscle (Walbaum, r899; Helander, 1960) and is associated with relatively narrow fibres (George \& Naik, 1958). The diameter of the fibres of psoas muscle is, in fact, only about half that of the fibres in longissimus dorsi in the adult bovine animal (Howard et al. 1960) and the former muscle has both a smaller store of glycogen (Howard \& Lawrie, 1956) and a lower aldolase content (Kronman et al. I960). Such features denote a muscle more capable of sustained power production than the longissimus dorsi (Lawrie, 1953).

On the other hand, over the period 4-32 months, the longissimus dorsi had a higher dry-matter content and a markedly higher content of total nitrogen, on both a wholetissue and a fat-free basis, than had the psoas, the high nitrogen content being accounted for by a generally greater content of non-protein, sarcoplasmic and myofibrillar fractions. Less consistently, the ratio myofibrillar nitrogen:total nitrogen was higher, and the stroma nitrogen lower, in the longissimus dorsi. Such characteristics would accord with a more advanced state of development (Helander, I957; Dickerson \& Widdowson, 1960 ) and thus, it may be supposed, with a greater potential for power production.

A similar contradiction is found when the thoracic and lumbar regions of the bovine longissimus dorsi are compared (Lawrie, I96I). Thus the contents of total, myofibrillar and sarcoplasmic nitrogen are higher in the thoracic region, which suggests a greater development beyond the newborn condition, but the thoracic region has nevertheless consistently less intramuscular fat at all stages of development from birth to maturity, which is apparently indicative of a lower capacity for sustained energy production.

Although the results presented demonstrate that analytical differences between psoas and longissimus dorsi muscles are generally consistent and systematic, some values are atypical. Thus the Aberdeen-Angus heifer differed from the other cattle in that the percentage of intramuscular fat was higher in the longissimus dorsi muscle than in the psoas. This difference in fat distribution is also true in the pig (Callow, 1938; McMeekan, I940 $a-c$ ), although in this species McMeekan (1940a-c) and Joubert (1956) showed, on the basis of relative postnatal changes in muscle weight and in muscle-fibre diameter, that the longissimus dorsi developed later than the psoas and would therefore be slower to enter the fattening phase of growth (Hammond, 1932).

Again, the iodine values of the intramuscular fat for both psoas and longissimus dorsi muscles of the Friesian steer were disproportionately high in relation to the percentage fat contents. It is clear that factors other than the degree of development 
must be considered in interpreting the differences in composition between muscles, however systematic these may be. Such factors presumably reflect aspects of functional specialization which have yet to be elucidated.

\section{SUMMARY}

I. Psoas major and longissimus dorsi muscles from five Ayrshire $\times$ Red Poll bulls, a Friesian and a West Highland steer and an Aberdeen-Angus heifer were analysed.

2. The content of intramuscular fat in the psoas muscle at the level of the $4^{\text {th }}, 5^{\text {th }}$ and 6th lumbar vertebrae was found to be greater than in the corresponding longissimus dorsi muscle, except in the Aberdeen-Angus heifer, for which the converse was true.

3. The dry weight of the muscle and the contents of total, myofibrillar, sarcoplasmic and non-protein nitrogen were almost invariably lower, and the content of stroma nitrogen higher, for the psoas than for the corresponding longissimus dorsi.

4. Conflicting views on the relative development of the two muscles arising from the findings are briefly considered.

The co-operation of the following is gratefully acknowledged: Mr P. Andrade, Central Market, Smithfield, London; Barnsley Co-operative Society, Barnsley, Yorks; Messrs Chivers and Sons Ltd, Histon, Cambs; Mr J. Elliott, Animal Research Centre, Agricultural Research Council, Compton, Berks.

Technical assistance was given by Messrs S. J. Dant, W. A. Deer and R. P. Houghton.

\section{REFERENCES}

Callow, E. H. (1938). Rep. Fd Invest, Bd, Lond., p. 45.

Dickerson, J. W. T. \& Widdowson, E. M. (1960). Biochem. F. 74, 247.

George, J. C. \& Naik, R. M. (1958). Nature, Lond., r81, 709.

Hammond, J. (1932). Growth and Development of Mutton Qualities in the Sheep, Ist ed. London: Oliver and Boyd.

Helander, E. (1957). Acta physiol. scand. 4I, Suppl. no. I4I.

Helander, E. (r96o). Acta morph. neerl.-scand. 2, 230.

Howard, A. \& Lawrie, R. A. (1956). Spec. Rep. Fd Invest. Bd, Lond., no. 63.

Howard, A., Lawrie, R. A. \& Lee, C. (1960). Spec. Rep. Fd Invest. Bd, Lond., no. 68.

Joubert, D. M. (1956). F. agric. Sci. 47, 59 .

Kronman, M. J., Weinberger, L. E. \& Winterbottom, R. J. (1960). Arch. Biochem. Biophys. 86, 238.

Lawrie, R. A. (1953). Biochem. F. 55, 305.

Lawrie, R. A. (1960). Brit. F. Nutr. 14, 255.

Lawrie, R. A. (196r). F. agric. Sci. 56, 249.

McMeekan, C. P. (1940a). F. agric. Sci. 30, 276.

McMeekan, C. P. (1940b). F. agric. Sci. 30, 387 .

McMeekan, C. P. (1940c). F. agric. Sci. 30, 5 I I.

McMeekan, C. P. (1941). F. agric. Sci. 31, I.

Walbaum, O. (1899). Virchows Arch. 158, 170. 